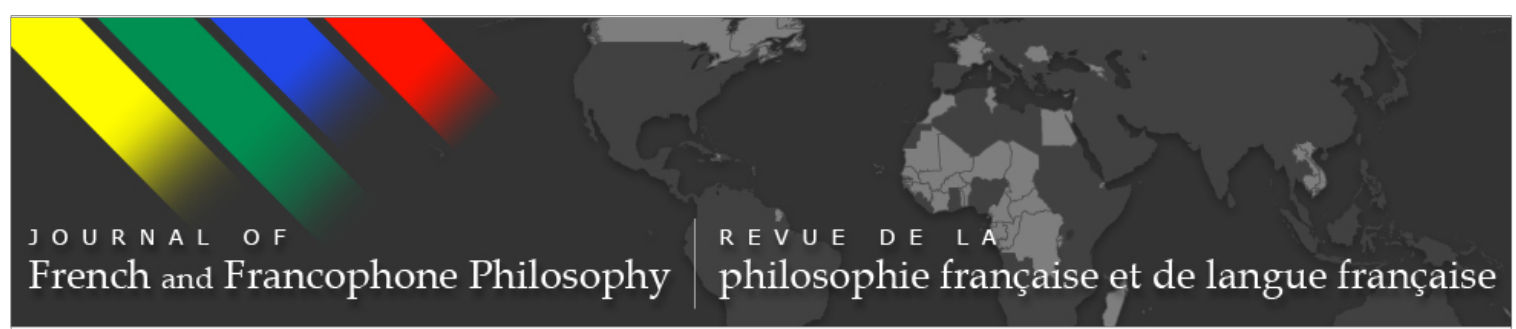

\title{
Kristeva's Sadomasochistic Subject and the Sublimation of Violence
}

\section{Kelly Oliver}

Journal of French and Francophone Philosophy - Revue de la philosophie française et de langue française, Vol XXI, No 1 (2013) pp 13-26

\author{
Vol XXI, No 1 (2013) \\ ISSN 1936-6280 (print) \\ ISSN 2155-1162 (online) \\ DOI 10.5195/jffp.2013.570 \\ www.jffp.org
}

\section{(oc) BY-NG-ND}

This work is licensed under a Creative Commons Attribution-Noncommercial-No Derivative Works 3.0 United States License.

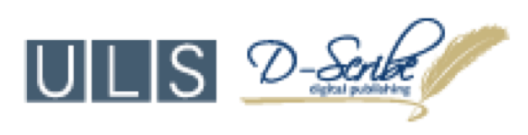

This journal is operated by the University Library System of the University of Pittsburgh as part of its D-Scribe Digital Publishing Program, and is co-sponsored by the University of Pittsburgh Press 


\title{
Kristeva's Sadomasochistic Subject and the Sublimation of Violence
}

\author{
Kelly Oliver
}

Vanderbilt University

Athena invented the rear-view mirror, which allows us to face the horror,
not face to face, but beginning from the duplicate, the simulacrum.
- Julia Kristeva, The Severed Head

Do representations of violence incite or quell violent desires and actions? This question - the question of the relation between mimesis and catharsis - is as old as Western Philosophy itself. In this essay, I attempt to think through how Kristeva might describe the difference between representations of violence that perpetuate violent desires and actions versus representations of violence that sublimate violent desires and thereby prevent violent actions. To my knowledge, Kristeva never gives a sustained and straightforward answer to this question. Indeed, her many discussions of language, representation and visual arts, along with theatre, dance, poetry, music, and installation pieces, suggest that artistic representation, and certain kinds of signifying practices, are sublimatory, that they can become productive homes-if only temporarily-for aggressive drives. Yet, exactly how and why some representations sublimate violence and others stimulate it is not so clearly delineated. This distinction becomes especially vexed when Kristeva criticizes the society of the spectacle in works such as New Maladies of the Soul and The Sense and Nonsense of Revolt. ${ }^{2}$ There, she argues that media spectacles are flattening psychic space and threatening to kill off the psyche or soul once and for all. This leads me to ask: what distinguishes representation as spectacle from representation as sublimation, or as transformation?

In more psychoanalytic terms, the question is: what distinguishes forms of representation that work through the sadomasochistic drives and inaugurate our entrance into language and society, from forms of representation that participate in acting out those aggressive instincts? My attempt to answer these questions will focus on two rarely discussed, but to my mind pivotal, texts in Kristeva's corpus: Kristeva's 1998 catalogue that

Journal of French and Francophone Philosophy | Revue de la philosophie française et de langue française Vol XXI, No 1 (2013) | www.jffp.org | DOI 10.5195/jffp.2013.570 
accompanied the exhibit of decapitated heads that she curated at the Louvre, entitled Capital Visions (recently translated for an English-speaking audience with the more graphic and spectacular title The Severed Head), and a talk that she gave at Columbia University in 2006 at a conference on the Dead Father, entitled "A Father is Being Beaten to Death," which is reflected in parts of her books This Incredible Need to Believe and Hatred and Forgiveness, written around that same time. ${ }^{3}$

\section{Kristeva's Rewriting of Totem and Taboo}

In part, both The Severed Head and "A Father is Being Beaten" are Kristeva's reworking of Freud's Totem and Taboo, ${ }^{4}$ particularly in relation to the sadomasochistic origins of subjectivity and signification. Kristeva puts sadomasochistic violence at the heart of signification itself, which for her can be a safeguard against violent acting out; but only if it doesn't become a new form of fundamentalism in the name of which we act out our most violent fantasies on the bodies of others. I will argue, for Kristeva, it is the precarious and interminable process of working through our sadomasochistic origins that determines whether or not we represent or act out, and whether or not our representations transform our violent impulses or merely feed them.

Since at least Powers of Horror, ${ }^{5}$ Kristeva has repeatedly returned to Freud's Totem and Taboo in order to retell the story of the primal horde, which not only inaugurates civil society with its taboos against murder and incest, but also inaugurates representation in all of its forms. This is a story of the violent origins of the primary processes of condensation and displacement that make signification possible and brand us as human beings. In a sense, it is Freud's answer to the most primal, yet most profound, of questions: where do we come from? I will argue that in Kristeva's retelling of the story of the origins of the speaking subject, Freud's murdered father becomes the beaten father, while Freud's forbidden mother becomes the beheaded mother. The father beaten to death and the beheaded mother not only inaugurate the prohibitions against murder and incest, as the Freudian story goes, but also open up the possibility of sublimating the violence necessary to become speaking subjects; a sadomasochistic violence that Kristeva insists is still necessary on both the individual and the social levels. To set the stage for Kristeva's latest revisions of the Freudian origin story, which revolves around the beaten father and the beheaded mother, first I will sketch some of her earlier engagements with Totem and Taboo in Sense and Nonsense of Revolt, and before that in Powers of Horror.

As we know, Freud gives a provocative explanation for the origins of idealization and sublimation that initiate religion, civil society and representation. This is a story of the body giving way to the law, and of the animal giving way to humanity. His story of what he calls a "band of brothers" who kills and eats what he calls their "father," and afterwards

Journal of French and Francophone Philosophy | Revue de la philosophie française et de langue française

Vol XXI, No 1 (2013) | http://www.jffp.org | DOI 10.5195/jffp.2013.570 
totemizes the father out of guilt; and then develops prohibitions against murder and incest in order to prevent any one of the brothers from meeting the fate of the father, is familiar to us. On this account, there was one superior male (the father) who hoarded the females and shunned the other males (the sons or brothers). Individually none of the other males could over-power the superior male, but one day they banded together to kill him and assimilate his power through their cannibalistic feast. At this point, they are not much different from a pack of wolves ripping into the alpha-dog. What distinguishes them from wolves, however, is that they subsequently idealize their "prey," the superior father, to the point that "[t]he dead father became stronger than the living one had been." ${ }^{6}$ Thus, they not only assimilate his power and restrict that power through internalized prohibitions or laws resulting both from their guilt but also from their submission to the ideal or symbolic father that now replaces the real one.

In Powers of Horror, Kristeva's most significant revision of the Freudian narrative is her insistence on the primary role of the maternal body in the cannibalistic, and subsequent ritualistic, meal. Here, it is the primal feast that fascinates Kristeva. And along with the prohibitions against murder and incest, she focuses on the prohibition against cannibalism at the dawn of humanity. This concern leads her to an analysis of food prohibitions in general, which she maintains always take us back to the maternal body, the first source of nourishment as well as the first source of frustration. Pleasure becomes anguish. Or, in the terms of Melanie Klein, the good breast becomes the bad breast, an ambivalence that Kristeva attempts to capture with her notion of the abject, which is both fascinating and horrifying.

Like Freud, Kristeva bases her analysis on anthropological literature, particularly Mary Douglas's study of filth and defilement. She suggests that fear of the generative power of the mother makes her body abject and inedible, and thereby makes all bodies abject and inedible. ${ }^{7}$ She says "I give up cannibalism because abjection (of the mother) leads me toward respect for the body of the other, my fellow man, my brother." ${ }^{8}$ Through the ambivalent struggle with the maternal body and the incest taboo, all human bodies become inedible.

On the level of the individual, Kristeva argues that an oral aggression related to both food and speech revolves around a fear of loss of the mother aggravated by threats of punishment by the father. ${ }^{9}$ The child feels aggression in response to its fear both of the loss of maternal satisfaction and of paternal prohibition instituted by the incest taboo. Kristeva sees a preobjectal aggression that comes from bodily drives and latches onto totemic symbols that stand in for, rather than represent, everything threatening and scary in the child's young life: "Fear and the aggressivity intended to protect me from some not yet localizable cause are projected and come back to me from the outside: 'I am threatened.'"10 The child responds to both deprivation and prohibition with aggressive impulses, which in the case of

Journal of French and Francophone Philosophy | Revue de la philosophie française et de langue française Vol XXI, No 1 (2013) | http://www.jffp.org | DOI 10.5195/jffp.2013.570 
the maternal body may literally include the urge to bite or devour, to incorporate, the maternal body in order to hold on to it.

The child's own aggressivity, then, is projected onto something outside of itself, for example a phobic animal, as a shield not only against the deprivation and prohibition exercised toward it by its parents but also against its own violent impulses. At this stage, these impulses revolve around incorporation as an attempt to devour and thereby possess the parental love (not-yet) object. At the same time that the child is learning language and incorporating the words of its parents, it is trying to incorporate them. For the infant, the mouth is the first center of bodily cathexis associated with pleasure, deprivation, and language acquisition. Words, like breast-milk and food, pass through its mouth. Kristeva interprets the phobic's fantasies of being bitten, eaten, or devoured by a scary animal as a projection of its own aggressive drives, particularly the urge to bite, eat, or devour the maternal body. As we will see, in The Severed Head, the mother's face becomes the quintessential figure for the condensation of the abject scary devouring mouth and the radiant reassuring loving smile.

In Sense and Nonsense of Revolt, Kristeva reads Freud's Totem and Taboo in terms of the assimilation of authority through cannibalism, or the assimilation of the body, and representation, or the assimilation of language. But, now she adds an emphasis on the break between the timelessness of animal instincts and bodily drives and the linear temporality of signification onto, and into, which they are discharged. She suggests that the institution of memory in the totemic rituals represses timelessness, the timelessness of the drives. Her invocation of archaic timelessness gives us another motive for the repetition of rituals that assimilate the authority and power of the primal father. Rather than just repeating the crime as a reminder of lack and debt on the one hand, and of the mobility of power on the other, repeating the timelessness of animal experience become bodily drive also frees us from prohibition and guilt and puts us in touch with the rhythms of the body and its pleasures and pains outside of linear time. Rather than merely repeat guilt and prohibition, idealization opens the space for a repetition of timelessness within linear time, a repetition that Kristeva identifies with the celebratory excess, or jouissance, of the feast. The origin story is not just the story of fixed totems or taboos, but also the story of how bodily drives become meaningful through signifying rituals even as they exceed those rituals. It is the story of animal instincts become human drives; ultimately it is the story of the fluidity of desire.

Desire is not conceived of as the flip side of prohibition; rather, desire reverberates with longing for an archaic timelessness of our embodiment. On the level of the social, this timelessness is associated with animality and the transition from animal to human, while on the level of the individual, it is associated with the infant's relation to the maternal body, and the

Journal of French and Francophone Philosophy | Revue de la philosophie française et de langue française Vol XXI, No 1 (2013) | http://www.jffp.org | DOI 10.5195/jffp.2013.570 
transition from dependence to independence. In a sense, this timelessness is the absolute unity of being and meaning - what Freud might call the death drive, and later what Kristeva associates with the timelessness of death itself, which is outside of time and invisible, but can be rendered visible through artistic representation: "Death exists outside time: we can't see it; we must be content with varying our capital visions of it. Absolute cult or ultimate revenge?"11

I will return to this question, but for now we can describe sublimation not only as a process of redirecting sexual and aggressive instincts à la Freud's totem and taboo, but also as a process of discharging the timelessness of the drives (of the animal and of the preoedipal subject) into time (the temporality of the human and of the individual). Indeed, as I have argued elsewhere, we can go further and diagnose Freud's account of the killing become murder and subsequent guilt become prohibition as a displacement of this archaic timelessness into taboos-Thou Shalt Not-that take the form of Universal Principles, Eternal Truths, or Divine (timeless) Commandments. ${ }^{12}$ This operation is the displacement of the timelessness of bodily drives into the Eternal through which Absolute Good becomes an unforgiving Ideal opposed to its abject opposite Absolute Evil. The ideals of Good and Evil are beyond the realm of our embodied finite animality, and thereby deny everything bodily and finite in life; which, of course, is the process that Freud describes in Totem and Taboo as the violent beginnings of religion.

In terms of psychoanalysis, this form of idealization becomes a harsh and punishing super-ego that makes extreme demands as a defense against contamination by its disowned and abjected otherness, which it must exclude to define itself as clean and proper. Kristeva associates this form of idealization and abjection with fundamentalism and the self-righteous violence to which it can lead. She says:

The pure and absolute subject-call him the purifierdefends himself against the maternal from which he is separating through anti-taint rituals while at the same time defending himself against the murder of the father through feelings of guilt, contrition, repentance. Therefore what appears to be purity in the eyes of the religion and the purifiers is only an obsessional surface that conceals a veritable architecture of purity... to fight the various forms of fundamentalism and violence that appear to be the sorry privilege of this end of the century [we need to take] into consideration what produces it, namely, the disgust with taint and the consequent contrition, repentance, and guilt that present themselves as qualities of religion but also profoundly constitute the psychical life of the being capable of symbolicity: the speaking being. ${ }^{13}$

Journal of French and Francophone Philosophy | Revue de la philosophie française et de langue française Vol XXI, No 1 (2013) | http://www.jffp.org | DOI 10.5195/jffp.2013.570 
In This Incredible Need to Believe, she calls this type of religious idealization that leads to violence the "malady of ideality."

We have now come full circle, back to a more nuanced version of the question with which we started: namely, what determines whether repetitions of the primal festival will take the form of violent acting out or sublimation of violence? Can we determine what rituals or signifying practices discharge the sadomasochistic drives at the heart of subjectivity by inflicting violence on others versus those that sublimate those drives and thereby transform the desire for violence and death into something creative? Within Kristeva's terminology, another version of our question is: what distinguishes perversion from sublimation? Certainly, the answer to this question has everything to do with the processes of idealization and representation that Freud describes in Totem and Taboo, and Kristeva elaborates throughout her work, as the move from animal to human on the social level, and on the individual level, the move away from the maternal body and towards the paternal law-what in everyday language, we call "weaning."

\section{A Mother is Being Beheaded}

Tracing our fascination with decapitation, beheading, and severed heads from prehistoric cave paintings through Warhol's Marilyn Monroe diptych, in The Severed Head, Kristeva repeatedly argues that all of these detached heads represent both the mother's face-that primal lost loving gaze-and representation itself insofar as we associate thought with the head. The figure of the head brings together our most archaic fears and desires along with our most effective means for sublimating them. Relating early cannibalistic rituals and skull fetishes to Freud's narrative of the primal horde, Kristeva once again transfers the originary founding violence from Freud's paternal figure to a maternal one. She claims:

the skull and the face, primary targets for the gaze, appear to us as privileged stations in the loss of maternal dependence. To assimilate the head of the other, to absorb the mother's milk of the brain...the cannibalistic ritual is as much if not more an appropriation of the mother's power than a devouring of the father-tyrant....Thus we may read in [the totemic feast] a double celebration: that of the rival phallic father and that of the mother who abandoned us ... From this totemic perspective, the assimilation of the head also seems to be a possible archaic equivalent for incest ... ${ }^{14}$

Indeed, she calls the phallic cover up of maternal power a "construction 'after the fact' [Nachträglich]." ${ }^{15}$ Thus, she concludes: "To eat, to kill, to possess, to represent." ${ }^{16}$

Journal of French and Francophone Philosophy | Revue de la philosophie française et de langue française

Vol XXI, No 1 (2013) | http://www.jffp.org | DOI 10.5195/jffp.2013.570 
On both the social and individual levels, we become speaking subjects by moving away from literal killing and eating and towards their metaphorical analogues in representations, assimilation and substitution. Rather than eating the primal father or the mother's milk, we assimilate their words; and rather than killing them, we substitute symbols that represent our violent impulses, for example, images of severed heads. Yet, Kristeva insists that these representations are sublimatory only insofar as they do not merely represent aggressive drives, but rather discharge them, and more importantly, transform them. In The Severed Head, she uses words like alchemy, transubstantiation, transformation, transfiguration, passage, modulation, osmosis, metabolization, compensation, and at the extreme, resurrection, salvation and rebirth, to describe the process by which representation sublimates bodily drives, particularly primal urges for cannibalism, incest, and murder.

As she does when describing the revolution in poetic language in her early work, she insists that the intimate revolt, as she now calls it, which she associates with becoming an individual and that is repeated in each sublimatory representation, is not mimesis or a copying of drives in language. ${ }^{17}$ Bodily drives are neither the objects represented nor the referents of those objects (or images or symbols as the case may be). Rather, through what she calls an imprint, an infiltration, an inscription of the body, a sign replaces the absent body, which always takes us back to the absent maternal body. The missing body, and at some level any missing object, including the phallus threated with castration, is always the mother's missing face, source of joy and terror. Kristeva claims that we hallucinate her, see her image, and then fabricate word-signs. We thereby compensate for our separation from her, for the cut, by taking control through representation: "For capital disappearance of mother's face, I substitute capital vision-images words language," which is another form of “incarnation." 18

As always, Kristeva emphasizes the materiality of representation. In The Severed Head, she discusses the material elements of drawing, painting, and sculpture. Through art, we can get distance from our wounds and give them meaning that allows us to work through trauma and protects us from the worst violence: "No bombast, no savagery, you are distanced and sheltered from the cannibals, the terrorists." ${ }^{19}$ Through art, she says, "slaughter turned to image assuages the violence, more or less repressed or mastered, of individuals and nations..." and through

... alchemy in which the representation comes of a grieving, a renunciation, a castration, a death. There is something beyond death, the artistic experience says, there is resurrection...Decapitation is a privileged space. Exulate, jubilate! ${ }^{20}$

Journal of French and Francophone Philosophy | Revue de la philosophie française et de langue française Vol XXI, No 1 (2013) | http://www.jffp.org | DOI 10.5195/jffp.2013.570 
The idea is that rather than decapitate, we draw or paint severed heads.

Kristeva goes so far as to say that these visions of severed heads are the opposite of acts of decapitation. Discussing the French Revolution and the Reign of Terror, she begins a chapter on the guillotine:

In opposition to the imaginary intimacy with death, which transforms melancholy or desire into representation and thought, lies the rational realization of the capital act. Vision and action are polar opposites here, and the revolutionary Terror confronts us with that revolting abjection practiced by humanity under the guise of an egalitarian institution of decapitation. ${ }^{21}$

She concludes the chapter, "the profusion of images and symbols has a chance of thwarting the temptations of real actions...After all, if art is transfiguration, it has political consequences." 22

At this point, it seems as if Kristeva answers our original question with a resounding affirmation, namely, that representations quell rather than incite violence; indeed, representations may be the only way to prevent the worst violence. And, although the question of whether all representation prevents violence is still an open one, we have begun to get some clues as to how representation can sublimate violent drives. First and foremost, representation transforms drives into something else (words, painting, sculpture) through which they are discharged without resorting to violence. Second, representation takes the place of the missing maternal face and thereby compensates for the absence and loss that incite violence and thereby softens and counterbalances the paternal prohibitions against cannibalism, murder and incest that allow us to live together without eating each other. Third, art-and we could add psychoanalysis-allow us to get distance from loss and pain, and this detachment protects us from their crippling effects.

In Hatred and Forgiveness, she likens this detachment to a mother's love for a child that she must let go; there, Kristeva calls this process "depassion," or "de-passioning," which is also a de-eroticizing necessary for sublimation of sadomasochistic drives that simultaneously threaten and inaugurate speech. In addition, artistic representation transforms the artist from a passive victim of trauma into an active agent of creativity. Thus, art transforms its subjects, in both senses of the word "subject": the subject matter of the work and the creator of the work. ${ }^{23}$

The relationship between the work of art and working through trauma takes us to our second, and more difficult, question: what sorts of representations prevent violence and what sorts actually incite violence? Certainly we have seen enough inflammatory rhetoric, particularly from religious fundamentalists of all sorts, to know that not all representation

Journal of French and Francophone Philosophy | Revue de la philosophie française et de langue française

Vol XXI, No 1 (2013) | http://www.jffp.org | DOI 10.5195/jffp.2013.570 
quells violence but rather some exhorts it. Kristeva begins to answer this question in The Severed Head when she suggests that in order to be sublimatory, representation has to avoid becoming dogmatic, ideological, or fundamentalist. Conversely, when it becomes dogmatic or ideological, it risks perpetuating rather than preventing violence. Indeed, it can become the ideal in the name of which we commit violent acts.

So, as Kristeva asks, how do we avoid becoming dogmatic and ideological? She answers:

Quite simply through talent that does not succumb to the object, that avoids the fetish...through the invention of an unprecedented form, which doesn't shrink from abjection but reshapes our vision so that we see it with new eyes. ${ }^{24}$

The object of art cannot become a fetish; rather, it must always be a passage, a transition, and fluid rather than fixed. We must concentrate on the work of art, in its double meaning, rather than the artwork as an object. It is the process of figuration, particularly the drive force or primary processes that motivate it that make art sublimatory, not the object of art per se. This is why one and the same art work or art object can aggravate or alleviate violence. And, why Kristeva maintains that we must be persistently "faithful[ness] to the cut," which simultaneously does both. We must leave open the wound, trauma or loss, the horror, out of which creative representation is born, and through which it offers us rebirth, as she would say. ${ }^{25}$

The difference, then, between spectacle that incites violence and art that sublimates it is that spectacles reinforce one way of seeing the world while works of art open up new ways of seeing; they are an "anti-metaphysical metaphysics," which constantly questions the foundations of all fundamentalisms: "abandon the spectacle and find a kind of face that has not yet found its face, that never will, but that never stops seeking a thousand and one ways of seeing. This is the intimacy they make us imagine, sensual seekers of the visible incarnation, the path of incarnation." 26 The process that Kristeva describes is an ongoing one of cathexis and de-cathexis that leads to more questions than answers. For, without constant questioning, any interpretation or belief risks becoming fetishized fundamentalism in the name of which we kill and "eat" each other.

\section{A Father is Being Beaten}

In the essay "A Father is Being Beaten to Death"-along with This Incredible Need to Believe-Kristeva continues to delineate the difference between forms of belief that open up questioning and those that close it down. There, she describes her analysis of the child's identification with a beating and suffering father as a rereading of Freud's Totem and Taboo, inflected by his theories in "A Child is Being Beaten," where the guilt that

Journal of French and Francophone Philosophy | Revue de la philosophie française et de langue française Vol XXI, No 1 (2013) | http://www.jffp.org | DOI 10.5195/jffp.2013.570 
underlies the beating fantasy is the underside of desire for the father. Following Freud, she argues that the beating fantasy is at the origin of individuation and subject constitution, and of sexual difference, now described in terms of differential relations to the beating fantasy. If, in The Severed Head, sadomasochism is "the secret of the unconscious," as Kristeva calls it, and takes center stage as the flip side of sublimation. Language is both derived from, and sublimates, sadomasochistic desires for incest and murder of both parents, on the one hand, and the superego's pleasure in self-punishment for those very desires on the other. Both the desires and their prohibitions are simultaneously channeled into representation. This, of course, is the familiar story of Freud's totem and taboo.

The guilt in killing the primal father comes from identification with him and his suffering, which is an essential part of the dynamic of substitution initiated by totemic rituals. In order for a symbol to substitute for the dead father, the son (or daughter) must first be able to identify with him and his suffering. And for Kristeva, the first substitution for the mother as object of incestuous desire is a narcissistic one, wherein the infant's own body takes the place of the missing maternal body, through autoeroticism. But in order for the next stage in the process of substitutions to take place, the intensity of the eroticism connected to sadomasochistic desires for both parents must be transferred to language. Representation itself becomes a new love object that enables us to survive the loss of the maternal body and skirt the punishment of the paternal law. ${ }^{27}$ We could simply say that through representation we cope with all loss, guilt and punishment, whether the traumatic loss of the mother's face and our infantile connections to our first caregivers, or the big and small losses and victimizations that we suffer throughout our lives. Indeed, in order to survive them, we must take pleasure, even if perverse pleasure, in representing our melancholy experiences. Kristeva postulates:

In addition to masochistic perversity ("I take pleasure in the fantasy of being beaten") is the sublimatory jouissance of my own capacity to say and to think for and with the beloved/loving. I want to emphasize that from the beginning sublimation accompanies this perverse defense, and perversion acts as sublimation's double. ${ }^{28}$

The sadomasochistic identification with the beaten father is a defense against the father of the law and his punishment and thereby an essential part of the process of idealization that enables the intimate revolts necessary for individuation. The suffering father is the latest incarnation of Kristeva's imaginary father introduced in Tales of Love as the necessary support of the move away from the maternal body and towards the paternal law. Here, the suffering father plays the role of bridge between the two. His incarnation and victimization allow the subject to bond with a paternal most like itself; that is to say, the infant or child as victim of the paternal law can find an alternate ideal in the father as victim. This identification supports the

Journal of French and Francophone Philosophy | Revue de la philosophie française et de langue française

Vol XXI, No 1 (2013) | http://www.jffp.org | DOI 10.5195/jffp.2013.570 
intimate revolt against the paternal authority that, in a paradoxical move, authorizes the subject and its entrance into the symbolic.

An identification with the beaten father counter-balances the punishing paternal super-ego by allowing the girl or boy sadomasochistic pleasure in punishment, which is doubled by sadistically turning the tables on the punishing father of the law and subjecting him to a beating, and then in turn masochistically identifying with his victimhood and what becomes sweet suffering. Kristeva observes: “Beaten, I join my father once again; we are united by these nuptials under the whip...we are both in love and guilty and both deserve to be beaten." ${ }^{29}$ The passion of Christ is Kristeva's prime example of the "a father is being beaten to death" fantasy. Substituting the Christian fantasy of the suffering Christ beaten to death, for the Freudian father murdered and eaten by the primal horde, Kristeva goes on to describe how identification with him supports the possibility of sublimation and the transfer of erotic intensity to symbolic activity itself:

The resexualization of the ideal father as Man of Passion brings about an unprecedented resexualization of representation itself, of the very activity of fantasizing and of speaking.... The activity of representing-speakingthinking, attributed to the father in patrilineal societies and which connects me to him, now becomes the privileged realm of sadomasochistic pleasure, the "kingdom" indeed, where suffering opens out, justifies and appeases itself ... Perversion and sublimation are the flip sides of this flexibility, if not of this fabulous suspension of the incest taboo induced by the beaten- todeath father. ${ }^{30}$

Again, Kristeva emphasizes incestuous desires and their taboos as the primary motivators for becoming speaking subjects. Representation not only compensates for the loss of these first loves, but also transforms desire for them into desire for language. Moreover, it transforms the passive victim of parental love and punishment into an active agent, while also turning the threatening parents into passive victims. The punishing father becomes the beaten father and the castrating mother becomes the beheaded mother. The perpetrator becomes the victim-but one with whom we identify; and, with these sadomasochistic fantasies we find both revenge and reunion through imaginary and symbolic satisfactions. In this way, we not only separate from our parents to become individuals, but also we cope with the pain of that separation, the separation that prefigures all others.

But, Kristeva also insists that imaginary and symbolic identification with suffering is a depassioning; so it is at once the transfer of erotic drives into representation and the transformation of those drives from passion to depassion, from eroticism to de-eroticism. And it is this transformation that

Journal of French and Francophone Philosophy | Revue de la philosophie française et de langue française Vol XXI, No 1 (2013) | http://www.jffp.org | DOI 10.5195/jffp.2013.570 
allows us to embrace them, that puts them beyond the taboo, and provides us with sublimatory jouissance. Ultimately, with and against the death drive, representation makes the primary separation-which comes to stand for all pain, loss, trauma, and the very meaninglessness of life-into something meaningful, even sacred. Kristeva says, "understood as a traversal, by thought, of the unthinkable: of nothingness, uselessness, the vain and the mad" we are confronted not with religion but with the sacred. ${ }^{31}$

This distinction between religion and the sacred brings us back to the fragile distinction between dogmatism and sublimation. When the sacred becomes fixed in religion, it becomes dogmatic and risks becoming fundamentalism through which we justify violence. It becomes the malady of ideality. But, if the process of idealization necessary for a meaningful life is held open to constant questioning and reinterpretation through new forms of representation, then there is the possibility for sublimation of the sadomasochistic drives, which might prevent such violence. Rather than latching on to the ideal and becoming fanatical about it, we open it up to new ways of seeing, new fantasies of death and rebirth.

This is what Kristeva does in her own work, signaled by her use of questions that provide different ways of interpreting the same phenomena. For example, when in The Severed Head, she asks, "What is the power of representation? Does the image succumb to the violence of death, or does it possess the gift of modulating it?" 32 This style of constant back-and-forthing, of either-or, of both/and, is also what sometimes makes her work frustrating and difficult to pin down. But also it is what opens it up to interpretation. Through the use of questions throughout her writing, she leaves open possibilities and complexities rather than closing them down or resolving them.

Kristeva maintains that the challenge to continually question our own investments in violence is unique to psychoanalysis. In her introduction to This Incredible Need to Believe, entitled "The Big Question Mark," she argues that speaking in analysis becomes a questioning that "renders us capable of new bonds...the bond of investment in the process of symbolization itself.",33 With its constant reinterpretations of our losses and frustrations, it allows us to take pleasure in the pain of separation and of reunion over and over again in language. "The founder of psychoanalysis," she says,

began by making love lie down on the couch. In order to return to the love of the father and the mother, and on taking the gamble... that 'I' am capable of going beyond my genitors indeed beyond myself and my loves, on the condition of being subject to perpetual dissolution in analysis, in transference and counter-transference. This presupposes that there is not only a Dead Father, but also figures of paternity and of loves, in the plural, in which I

Journal of French and Francophone Philosophy | Revue de la philosophie française et de langue française Vol XXI, No 1 (2013) | http://www.jffp.org | DOI 10.5195/jffp.2013.570 
take pleasure, which I kill and which I resuscitate when I speak, love and think. ${ }^{34}$

Even more than art, psychoanalysis allows us to kill and resuscitate in speech as protection against the pain and suffering caused by our violent drives.

Like Athena protected by (and from) Medusa's head, psychoanalysis provides a rearview mirror in which we can see ourselves reflected over and over again in new ways. By so doing, with and against religion and its too often deadly call for violence, psychoanalysis opens up the sacred space of intimate revolt, which Kristeva calls "psychic space or the life of the mind," or we could say, thought itself. Psychoanalysis acts as a counterbalance to the deadly force of fundamentalisms by offering:

a space for reflection in which the effort of clarification takes precedence over the deadly confrontation between a tendency for regression on the one hand and the explosion of the death drives on the other, which together now threaten our globalized humanity. ${ }^{35}$

1 Julia Kristeva, The Severed Head: Capital Visions, trans. Jody Gladdings (New York: Columbia University Press, [1998] 2012), 30.

2 Julia Kristeva, The Sense and Non-Sense of Revolt, trans. Jeanine Herman (New York: Columbia University Press, [1996] 2000) and New Maladies of the Soul, trans. Ross Guberman (New York: Columbia University Press, [1993] 1995).

${ }^{3}$ Kristeva, The Severed Head; Julia Kristeva, Hatred and Forgiveness, trans. Jeanine Herman (New York: Columbia University Press, [2005] 2010); Julia Kristeva, This Incredible Need to Believe, trans. Beverley Bie Brahic (New York: Columbia University Press, [2006] 2009); and Julia Kristeva, “A Father Is Being Beaten to Death," paper presented at Columbia University Press (2006).

${ }^{4}$ Sigmund Freud, Totem and Taboo, trans. James Strachey (New York: Norton, 1913).

5 Julia Kristeva, Powers of Horror, trans. Leon Roudiez (New York: Columbia University Press, [1980] 1982).

${ }^{6}$ Freud, Totem and Taboo, 501.

${ }^{7}$ Kristeva, Powers of Horror, 78.

${ }^{8}$ Kristeva, Powers of Horror, 79; parentheses in the original. 
${ }^{9}$ Kristeva, Powers of Horror, 39.

${ }^{10}$ Kristeva, Powers of Horror, 39.

${ }^{11}$ Kristeva, The Severed Head, 123.

12 See Kelly Oliver, The Colonization of Psychic Space: Toward a Psychoanalytic Social Theory of Oppression (Minneapolis: Minnesota University Press, 2004).

${ }^{13}$ Kristeva, Sense and Non-Sense, 22

${ }^{14}$ Kristeva, The Severed Head, 16-17.

${ }^{15}$ Kristeva, The Severed Head, 82.

${ }^{16}$ Kristeva, The Severed Head, 17.

${ }^{17}$ Kristeva, The Severed Head, 50-51.

${ }^{18}$ Kristeva, The Severed Head, 5-6.

${ }^{19}$ Kristeva, The Severed Head, 86.

${ }^{20}$ Kristeva, The Severed Head, 75-76.

21 Kristeva, The Severed Head, 91.

22 Kristeva, The Severed Head, 101-2.

${ }^{23}$ Kristeva, The Severed Head, 63.

${ }^{24}$ Kristeva, The Severed Head, 108.

${ }^{25}$ Kristeva, The Severed Head.

${ }^{26}$ Kristeva, The Severed Head, 127.

${ }^{27}$ See Kristeva, "A Father is Being Beaten."

${ }^{28}$ Kristeva, "A Father is Being Beaten," 4.

${ }^{29}$ Kristeva, "A Father is Being Beaten," 5, 6.

${ }^{30}$ Kristeva, "A Father is Being Beaten," 7.

${ }^{31}$ Kristeva, "A Father is Being Beaten," 8.

${ }^{32}$ Kristeva, The Severed Head, 10.

33 Kristeva, This Incredible Need, xv.

${ }^{34}$ Kristeva, "A Father is Being Beaten," 11.

${ }^{35}$ Kristeva, "A Father is Being Beaten," 11.

Journal of French and Francophone Philosophy | Revue de la philosophie française et de langue française Vol XXI, No 1 (2013) | http://www.jffp.org | DOI 10.5195/jffp.2013.570 